failures have preceded the attainment of the 26 -in. diameter, and Chance and Co. are said to be the only firm in the world who will undertake the manufacture of a disc of that size. Science knows no country, and $\mathrm{Mr}$. Lick's munificent bequest in the cause of astronomy will be hailed by savans all over the world.

\section{MENTAL POTENTIALITY IN CHILDREN OF DIFFERENT RACES}

MONS. J. C. HOUZEAU, the author of the "Études sur les facultés mentales des animaux comparées a celles de l'homme,"has lately concluded, in Jamaica, a series of laborious experimental investigations on the relative or comparative intellectual capacity and development of the children of different races inhabiting that island. The conclusions arrived at by such an observer are worthy of the highest consideration in Europe : while the subject is one that has an important bearing on various popular educational, ethnological, and social questions of the daysuch as the unity of mankind, and the possibility or probability of civilising savage races $A$ recent letter addressed to me by $M$. Houzeau, contains the following brief account of his experiments and conclusions; an account that cannot fail, I think, to be interesting to the readers of NATURE.

"I have been busy, meanwhile, on a curious study about the comparative development of intelligence of children belonging to different races. I had an opportunity here to submit to the test black, brown, and white children. Fifteen of them were sent to me every day for two hours by their parents, my country neighbours : three of them white, seven coloured of various shades, and five black. For a whole year I gave them myself common instruction, and carefully watched their proceedings and their rate of improvement. I do not expect to publish anything about that experiment, at least at this time. But I will state here the conclusions to which it has led me.

"I. There is in each child a different degree of intellectual proficiency, which could be called, in mathematical language, his or her 'personal coefficient.' However, these individual differences are much less than I had anticipated, and are not the striking feature in the unequal rate or speed of improvement.

" 2. In this unequal speed, I see nothing-at least nothing clearly and unmistakably discernible-that can be referred to the differences of race. This will probably appear strange after all that has been said of "inferior races.' Should other facts show that my experiment was not properly conducted, and that the trial was not conclusive, I am ready to give up. Still, it is at least my 'provisional conclusion.'

"3. The rate of improvement is due almost entirely to the relative elevation of the parental circle in which children live-- the home influence. Those whose parents are restricted to the narrowest gauge of intellectual exercise, live in such a material and coarse milieu, that their mental faculties remain slumbering and gradually become atrophied; while those who hear at home of many things, and are brought up to intellectual life, show a corresponding proficiency in their learning.

"The question of course would require more space and developrnent. I rather mention it as a subject for study than anything else. I had in my life some rare opportunities to stuciy 'inferior races,' including Indians of America, and 'hall-breed Indians' of the mixed race of Mexict. I believe most of the savans of Europe have but a very incomplete idea of the mental, and still more of the moral, status of 'inferior societies.' Much remains to be said about it."

My pres.ne objec: being briefly to introduce to English reacers $M$. Houzciu's views as to the relative intellectuality of the children of different races in Jamaica, I will not here explain in what respects I differ from his conclusions-how far I regard his experiments inconclusive. I would only remind him, as well as the reader, of the impossibility of duly estimating the direction or amount of future or adult mental development by the study of mental phenomena in the young. It has been, I think, proved, for instance, that-

I. At or up to a certain age girls are as sharp as, or sharper than, boys at lesson-learning and repeat. ing. Cases are constantly being recorded-perhaps paraded-in the newspapers of girls or young women beating boys or young men of equal age in competitive examinations. And yet it is not to be inferred that the female mind is either superior or equal to the male, that is, in a comparison of averages. For the fact is, that throughout the animal series, including Man, the female mind is, in some respects, different from, and inferior to, that of the male. We know, moreover, that female supe riority, when it exists, is usually at least confined to school life. In subsequent intellectual development proper, man, as a rule, far surpasses woman. Again-

2. Up to a certain point there is the closest possible parallelism between the mental endowments of the human child and of the young of sundry other animals. At certain stages of development, and in certain animals, the comparison is not even in favour of the child. And yet, though we are still far from knowing what is the range of the mental potentialities of other animals than man, we have no reason for supposing that in any of them will the maximum intellectual or moral development attain to the average in cultured and civilised man.

W. LAUDER LINDSAY

\section{NOTES}

AT a recent meeting of the Trustees of the "Gilichrist Educa. tional Trust," they decided to appropriate a sum not exceeding I, $000 l$. to the promotion of scientific research, with the prospect of repeating this grant annually if it should bear adequate fruit. The plan proposed is to ask the Council of the Royal Society to make recommendations to the Trustees, stating in each case the object of the research, the qualifications of the individual by whom it is to be conducted, and the sum they propose to be assigned to him ; the purpose of the grant being to assist men of science who have shown themselves capable of advancing science, and who may feel themselves precluded from devoting their time to unvemuntrated work, by freeing them from the necessity of giving up investigations of great promise for the sake of mere bread-earning. We believe that this important movement is due to the representations of Dx. Carpenter, the Secretary, to the Trustees, that they would be in this mode worthily applying about a fourth part of their income in meeting a great national want, and in promoting the second of the objects as to which they have an uncontrolled discretion under the will of the founder- "The benefit, advancement, and propagation of learning in every part of the world." The Council of the Royal Society has, we understand, appointed a Committee to consider the conditions under which the Council may most fittingly undertake the responsibility of advising the Gilchrist Trustees as to the appropriation of their grants.

TrEe matter in dispute between the President and Council of the Linnean Society and a certain section of the Fellows, which caused so much excitement in the Society some montlis ago, and led to the premature retirement of Mr. Bentham from the cbair, was referred to Lord Hatherley as arbitrator, and has just been decided entirely in favcur of the President and Council; so that no further action will be taken in the matter.

W1 regret to record the death, on July $3 \mathrm{I}$, of Dr. Charies $\mathrm{T}$. Beke, whose name is so well known in connection with geogra. phy, etlinology, and philology. 